\title{
Quality of Life and Work Ability among Healthcare Personnel with Chronic Viral Hepatitis. Evaluation of the Inpatient Rehabilitation Program of the Wartenberg Clinic
}

\author{
Claudia Westermann ${ }^{1, *}$, Albert Nienhaus ${ }^{1,2}$ and András Treszl ${ }^{1}$ \\ 1 Competence Centre for Epidemiology and Health Services Research for Healthcare Professionals (CVcare), \\ University Medical Centre Hamburg-Eppendorf (UKE), 20246 Hamburg, Germany; \\ albert.nienhaus@bgw-online.de (A.N.); andras.treszl@hotmail.de (A.T.) \\ 2 Department of Occupational Medicine, Hazardous Substances and Public Health, Institution for Statutory \\ Accident Insurance and Prevention in the Health and Welfare Services (BGW), 22089 Hamburg, Germany \\ * Correspondence: c.westermann@uke.de
}

Received: 24 September 2019; Accepted: 9 October 2019; Published: 12 October 2019

check for updates

\begin{abstract}
The aim of this study was to research the impact of inpatient rehabilitation on work ability and health-related quality of life factors for healthcare personnel (HP) with chronic hepatitis B and $\mathrm{C}$ virus (HBV and $\mathrm{HCV}$ ) infection. A prospective evaluation study with three data collection times without an external control group was conducted. HP $(n=163)$ with an occupational acquired chronic hepatitis $\mathrm{B} / \mathrm{C}$ infection who participated in an inpatient rehabilitation program were surveyed. Information was collected on work ability (WAI-Work Ability Index), quality of life (SF-36-Short Form-36 Health Survey), and anxiety and depression-related symptoms (HADS-D-Hospital Anxiety and Depression Scale). The majority of participants had HCV infection. Work ability was poor, improved significantly until the end of treatment, and remained at a moderate level six months later. The SF-36 showed no change in physical health over the study period, the results regarding mental health were in the average range with a significant improvement directly after intervention. The HADS-D results indicate noteworthy anxiety and depression symptoms during the study period. The inpatient rehabilitation program proved to be effective in the short term regarding mental health (SF-36) and WAI. To ensure long lasting positive results, services aimed at enhancing physical and mental health should be provided as early as possible and on a recurring basis.
\end{abstract}

Keywords: chronic hepatitis; occupational disease; work ability; quality of life; mental health; inpatient rehabilitation

\section{Introduction}

Hepatitis $\mathrm{B}$ and $\mathrm{C}$ virus (HBV and $\mathrm{HCV}$ ) infections are among the most common blood-borne infectious diseases in the world. According to recent estimates from the World Health Organisation (WHO), 3\% of the world's population (around 240 million) suffers from a chronic HBV infection, while $1 \%$ (around 71 million) suffers from a chronic HCV infection [1,2]. These infections have potentially severe progressions that can result in work incapacity and mortality. In up to $10 \%$ of HBV and $85 \%$ of $\mathrm{HCV}$ cases, the infection is chronic. More than 1.34 million deaths each year are attributed to chronic viral hepatitis as the underlying cause [1]. Chronic HBV and HCV infections are among the most significant causes of hepatic cirrhosis and hepatocellular carcinoma [3,4]. Healthcare personnel (HP) have contact with infected patients as part of their work. Of particular note are invasive procedures that involve a risk of injury for employees [5]. HP have had access to HBV vaccinations since the 1980s, 
but there is neither a vaccination nor post-exposure prophylaxis for HCV. The chronic progression of the infection has an impact on both work ability and on the health-related quality of life of patients. Moreover, neuropsychiatric symptoms are observed among patients with chronic HCV infections that may be intensified as a result of treatments using pegylated interferon (PEG-IFN) [6]. The direct impact of HCV on the central nervous system is assumed to be a cause of cognitive impairment [7]. In recent years in Germany, the number of claims concerning viral hepatic infections filled to the compensation board decreased [8]. HP with occupationally-contracted viral hepatitis receive support from the compensation board for many years because of the chronic nature of the infection. The benefits offered to insured persons include an inpatient rehabilitation program at the Wartenberg Clinic in Bavaria. These inpatient rehabilitation programs may differ in terms of their nature and focus, but frequently consist of rehabilitative measures with the aim of counteracting the disease-related reduction in performance and fatigue symptoms through medical training therapy and other activating physical therapies and psychological counselling. The aim of this study was to describe work ability and health-related quality of life factors for HP with chronic hepatitis B or C and to analyse the impact of the inpatient rehabilitation program on work ability and health-related quality of life.

\section{Materials and Methods}

\subsection{Study Design, Sample, and Measurements}

We performed a prospective evaluation study with three data collection times without an external control group. HP with a chronic $\mathrm{HBV} / \mathrm{HCV}$ infection recognised as an occupational disease who participated in a four-week inpatient rehabilitation program at the Wartenberg Clinic between April 2015 and December 2017 were eligible for the study. Using standardised questionnaires, self-reported information was collected on work ability, health-related quality of life, and anxiety and depression-related symptoms directly before (T1) and after the treatment program (T2) and six months later (T3). Work ability was determined using the German version of the work ability index (WAI score 7-49 points ( $\mathrm{p}), \leq 27 \mathrm{p}=$ poor, $28-36 \mathrm{p}=$ moderate, $37-43 \mathrm{p}=$ good, $\geq 44 \mathrm{p}=$ excellent) [9]; WAI single item, current work ability compared with the best work ability ever achieved $(0-10 p, \leq 5 p=$ poor, $6-7$ $p=$ moderate, $8-9 p=$ good, $10 p=$ excellent [10]). The WAI was only used for the professionally active subgroup. The health-related quality of life was determined using the German version of the Short Form-36 Health Survey (SF-36). Mean values for the Physical Health Summary Scale (PHSS) and Mental Health Summary Scale (MHSS) were provided (0-100 p per scale, $100 \mathrm{p}$ corresponding to the highest value achievable, $0 \mathrm{p}$ corresponding to the lowest). The baseline from the reference sample for both scales was $50 \mathrm{p}$ with a standard deviation (SD) of $10 \mathrm{p}$ [11]. Anxiety and depression were determined using the German version of the Hospital Anxiety and Depression Scale (HADS-D); an instrument that measures mental stress among somatic patients. It consists of two subscales, the anxiety subscale (HADS-D A) and the depression subscale (HADS-D D). Each consists of seven questions and has to be analysed independently. Higher values indicate a greater impairment. The mean values from the anxiety and depression scales were provided ( $0-21 \mathrm{p}$ per scale, $\leq 7 \mathrm{p}=$ normal, $\geq 11 \mathrm{p}=$ noteworthy symptoms) [12]. During the admission consultation with the physician, a clinical survey was used to collect information on general condition (e.g., body mass index (BMI), physical activity) and on medical history (e.g., reduced work ability (RWA), liver condition, therapy history, mental stress). Blood samples were also collected to determine viremic and hepatic values. At T2, participants were surveyed regarding their satisfaction with the care (physicians, nurses, physiotherapists, and psychiatrists), accommodation, and catering. The individuals' goals for rehabilitation and their assessment regarding objective achievement were also queried.

\subsection{Power Estimation}

A power estimation was performed based on the recommendations of Walters and colleagues [13] regarding the outcome of health-related quality of life (SF-36). Taking into account a minimum 
difference of five points in the mean value on the $0-100$ scale and an SD of 20 for the calculation of the required power, the number of cases was calculated using OpenEpi, version 3.03a (Open Source Epidemiologic Statistics for Public Health). Assuming a normal distribution for the t-test for dependent samples, the power estimation resulted in a sample size of $n=128$ (alpha error 0.05, two-sided, power $80 \%$ ). A drop-out rate of $10 \%$ was also assumed, resulting in a target sample size of 141 participants.

\subsection{Statistical Analyses}

Descriptive statistics as an absolute number (frequency) and mean (SD) are given. Univariate comparisons were performed using the Chi-square test for dichotomous, Fisher's exact test for categorical, and $t$-test for continuous variables. The Mann-Whitney $U$ test was used for non-normally distributed continuous variables. In order to quantify the therapy success, mixed models with participants as a random effect were calculated. Model-based mean values and $95 \%$ confidence intervals (CI) were adjusted for age and sex and stratified for the type of hepatitis. In the case of a significant time effect, individual time points were compared using contrasts. We specified nominal $p$-values without correction for multiplicity; $p$-values $<0.05$ were considered to be statistically significant. The statistical analyses were performed using SAS 9.4 (SAS Institute Inc. 2013. SAS ${ }^{\circledR 9}$ 9.4, Cary, NC, USA).

\subsection{Ethical Approval}

The competent local ethics committee issued a positive vote to collect and analyse the data in accordance with the guidance of the Helsinki Declaration of the World Medical Association (last revised in 2013) before data collection began (ethical code PV5017). For study purposes, no blood tests were performed. The results of routinely taken blood tests during the admission consultation were obtained after consent of the patients. This approach was defined and supported in the ethics proposal. All subjects of the study consented in writing to their participation in the study. Participation in the study was voluntary. The nature of and measures involved in rehabilitation are not affected by participation or non-participation.

\section{Results}

During the study period, 245 insured persons with chronic viral hepatitis participated in the treatment program at the Wartenberg Clinic. Of these, 163 insured persons participated in the study directly before and after the treatment. This is equivalent to a response rate of $67 \%$ at $\mathrm{T} 1$ and $\mathrm{T} 2$. Six months later (T3), the number of participants was 149 , or $61 \%$. During the study period, $40 \mathrm{HP}$ participated in the treatment program twice. Only the first participation was included in the mixed models analysis.

\subsection{Description of the Cohort}

The majority of participants were female (75\%) and the average age was 63 (SD 9) years. About $40 \%$ of participants were professionally active $(n=66)$, and these were on average 56 years old (SD 6). The majority of participants had completed a middle school education, worked in nursing professions, were married, and had an average monthly net household income of under $€ 2000$. In the professionally-active subgroup, the net household income was above $€ 2000$ in the majority of cases (Table 1).

The analysis of the subgroups by gender and type of hepatitis revealed significant differences for some sociodemographic parameters. HCV patients had an average age of four years below HBV patients. Median net household income for women was statistically significantly lower than for men $(p<0.001)$. The monthly net household income was less than $€ 2000$ for women and between $€ 2000$ and $<€ 4000$ for men. Women were more likely to be single or widowed ( $25 \%$ vs. $8 \%, p=0.04)$ and more likely to live in single households than men ( $34 \%$ vs. $21 \%, p=0.04)$. 
Table 1. Sociodemographic information (healthcare personnel $n=163$ ).

\begin{tabular}{|c|c|c|c|c|c|c|}
\hline \multicolumn{2}{|r|}{ Variable * } & \multirow{2}{*}{$\begin{array}{c}\text { Total } \\
163(\%)\end{array}$} & \multirow{2}{*}{$\begin{array}{c}\text { Working } \\
66(\%)\end{array}$} & \multirow{2}{*}{$\begin{array}{c}\text { HCV } \\
132(\%)\end{array}$} & \multirow{2}{*}{$\frac{\text { HBV }}{(31 \%)}$} & \multirow[t]{2}{*}{$p$ Value } \\
\hline $\mathrm{HP}$ & & & & & & \\
\hline \multirow[t]{2}{*}{ Gender } & Female & $123(75)$ & $56(85)$ & $104(79)$ & $19(61)$ & $p=0.32$ \\
\hline & Male & $40(25)$ & $10(15)$ & $28(21)$ & $12(39)$ & \\
\hline Age & Mean (SD) & $63(9)$ & $56(6)$ & $62(9)$ & $66(9)$ & $p=0.03$ \\
\hline \multirow[t]{2}{*}{ Nationality } & German & $151(95)$ & $60(94)$ & $124(96)$ & $27(90)$ & $p=0.34$ \\
\hline & Other & $8(5)$ & $4(6)$ & $5(4)$ & $3(10)$ & \\
\hline \multirow[t]{2}{*}{ Place of birth } & Germany & $129(79)$ & $55(83)$ & $108(82)$ & $21(68)$ & $p=0.10$ \\
\hline & Other & $34(21)$ & $11(17)$ & $24(18)$ & $10(32)$ & \\
\hline \multirow[t]{4}{*}{ Marital status } & Single & $17(10)$ & $10(15)$ & $17(13)$ & - & $p=0.59$ \\
\hline & Married & $96(59)$ & $38(57)$ & $74(56)$ & $22(71)$ & \\
\hline & Divorced & $32(20)$ & $13(20)$ & $28(21)$ & $4(13)$ & \\
\hline & Widowed & $18(11)$ & $5(8)$ & $13(10)$ & $5(16)$ & \\
\hline \multirow[t]{5}{*}{ Household } & Single & $51(31)$ & $18(27)$ & $42(32)$ & $9(29)$ & $p=0.19$ \\
\hline & With Partner & $84(51)$ & $29(43)$ & $63(48)$ & $21(68)$ & \\
\hline & With Partner and Child(s) & $22(14)$ & $15(23)$ & $21(16)$ & $1(3)$ & \\
\hline & With Child(s) & $2(1)$ & $1(2)$ & $2(1)$ & - & \\
\hline & With Relatives or Friends & $4(3)$ & $3(5)$ & $4(3)$ & - & \\
\hline \multirow[t]{4}{*}{$\begin{array}{l}\text { Highest Level } \\
\text { of Education }\end{array}$} & Secondary School & $32(20)$ & $9(14)$ & $25(19)$ & $7(24)$ & $p=0.29$ \\
\hline & $\begin{array}{l}\text { Polytechnic Secondary } \\
\text { School }\end{array}$ & $78(48)$ & $35(53)$ & $66(51)$ & $12(41)$ & \\
\hline & Higher Education & $46(28)$ & $21(32)$ & $37(28)$ & $9(32)$ & \\
\hline & Other & $4(4)$ & $1(1)$ & $3(2)$ & $1(3)$ & \\
\hline \multirow[t]{5}{*}{ Occupation } & Physician & $15(9)$ & $5(8)$ & $11(9)$ & $4(13)$ & $p=0.98$ \\
\hline & Nurses & $69(44)$ & $27(41)$ & $57(44)$ & $12(40)$ & \\
\hline & Nursing Home Nurse & $8(5)$ & $3(5)$ & $5(4)$ & $3(10)$ & \\
\hline & Nurse's Assistant & $13(8)$ & $3(5)$ & $8(6)$ & $5(17)$ & \\
\hline & $\begin{array}{l}\text { Medical-Technical } \\
\text { Assistant }\end{array}$ & $54(34)$ & $27(41)$ & $48(37)$ & $6(20)$ & \\
\hline \multirow[t]{3}{*}{$\begin{array}{l}\text { Net household } \\
\text { income in } €\end{array}$} & $<2000$ & $82(50)$ & $28(47)$ & $65(55)$ & $17(61)$ & $p=0.84$ \\
\hline & 2000 to $<4000$ & $54(33)$ & $27(45)$ & $45(38)$ & $9(32)$ & \\
\hline & $\geq 4000$ & $10(7)$ & $5(8)$ & $8(7)$ & $2(7)$ & \\
\hline \multirow[t]{2}{*}{ grouped } & $<2000$ & $82(56)$ & $28(47)$ & $65(55)$ & $17(60)$ & \\
\hline & $\geq 2000$ & $64(44)$ & $32(53)$ & $53(45)$ & $11(40)$ & \\
\hline
\end{tabular}

* \% based on valid values; HP healthcare personnel; $p$-Value (Chi-square for dichotomous, Fisher's exact test for categorical variables, and t-test for continuous variables). HCV hepatitis $\mathrm{C}$ virus; HBV hepatitis $\mathrm{B}$ virus.

Non-responders (no table): Insured persons who refused to participate $(n=82)$ were on average 63 years old (SD 9) and $81 \%$ female. Of these, $30 \%$ were professionally active. Only four persons specified reasons for their refusal; that is, advanced age, advanced hepatic cirrhosis, an existing care level, and anonymity concerns.

\subsection{Results of the Clinical Survey}

The majority of participants suffered from a chronic HCV infection $(n=132,81 \%)$; the most frequent was a genotype 1 infection ( $88 \%$ ), and only a few had a genotype 2 infection (5\%) or a genotype 3 infection (7\%). The time of infection for two-thirds of the insured persons was between 20 and 40 years previously. About $64 \%(n=98)$ of the participants had received at least one interferon treatment in the past, in some cases with persistent side effects $(n=34,35 \%)$. In the majority of cases $(n=49)$, current and completed interferon-free therapies were without major adverse side effects. A detectable viremia was present at $\mathrm{T} 1 \mathrm{in} 86 \mathrm{HP}(n=61 \mathrm{HCV}, n=25 \mathrm{HBV})$, with 21 professionally-active participants among them $(n=14 \mathrm{HCV}, n=7 \mathrm{HBV})$. A documented RWA of $20 \%$ or higher (of relevance for pension purposes) had $96 \%$ of the participants. Fibrosis was diagnosed in $66 \%$ and cirrhosis in $28 \%$ of cases. Eight insured persons showed a hepatocellular carcinoma in their medical history, while six had 
undergone a liver transplant. Of the professionally-active, four and two persons, respectively, were affected (Table 2).

Table 2. Clinical parameters stratified by type of hepatitis.

\begin{tabular}{|c|c|c|c|c|c|}
\hline & Variable * & Total & Working & $\mathrm{HCV}$ & HBV \\
\hline $\begin{array}{l}\text { Healthcare } \\
\text { Personnel }\end{array}$ & & $163(\%)$ & $66(\%)$ & $132(\%)$ & $31(\%)$ \\
\hline \multirow[t]{5}{*}{$\begin{array}{l}\text { Chronic } \\
\text { Hepatitis for }\end{array}$} & $<10$ years & $2(1)$ & $2(3)$ & $5(4)$ & - \\
\hline & 10-19 years & $32(22)$ & $11(18)$ & $26(21)$ & $3(12)$ \\
\hline & 20-29 years & $59(40)$ & $25(42)$ & $47(39)$ & $12(46)$ \\
\hline & 30-39 years & $43(29)$ & $19(32)$ & $34(28)$ & $8(30)$ \\
\hline & $40-49$ years & $12(8)$ & $3(5)$ & $10(8)$ & $3(12)$ \\
\hline \multirow[t]{6}{*}{ Liver Status } & Fibrosis & $107(66)$ & $52(80)$ & $93(70)$ & $14(47)$ \\
\hline & Cirrhosis & $46(28)$ & $8(12)$ & $33(25)$ & $13(43)$ \\
\hline & Without Findings & $10(6)$ & $6(8)$ & $5(5)$ & $4(10)$ \\
\hline & & & & \multicolumn{2}{|c|}{$p=0.04$ * } \\
\hline & $\mathrm{HCC}$ & $8(5)$ & $4(6)$ & $5(4)$ & $3(10)$ \\
\hline & LTX & $6(4)$ & $2(3)$ & $5(4)$ & $1(3)$ \\
\hline \multirow[t]{2}{*}{ RWA } & $<50$ & $101(64)$ & $56(86)$ & $82(62)$ & $19(61)$ \\
\hline & $\geq 50$ & $57(36)$ & $9(14)$ & $45(38)$ & $12(39)$ \\
\hline $\begin{array}{l}\text { Interferon } \\
\text { Experience }\end{array}$ & Yes & $98(64)$ & $34(55)$ & $91(31)$ & $7(39)$ \\
\hline \multirow[t]{6}{*}{ Therapy } & Current & $23(14)$ & $13(20)$ & $6(5)$ & $17(55)$ \\
\hline & Interferon-free & $21(13)$ & $13(20)$ & $6(5)$ & $16(48)$ \\
\hline & $\begin{array}{l}\text { completed } \\
\text { compatibility }\end{array}$ & $28(17)$ & $7(11)$ & $28(21)$ & - \\
\hline & good & $43(88)$ & $16(94)$ & $29(83)$ & $16(100)$ \\
\hline & moderate & $5(10)$ & $1(6)$ & $5(14)$ & - \\
\hline & bad & $1(2)$ & - & $1(3)$ & - \\
\hline \multirow[t]{6}{*}{$\begin{array}{l}\text { Laboratory } \\
\text { values }\end{array}$} & $\mathrm{AST}^{\mathrm{a}}$ increased & $72(44)$ & $28(42)$ & $69(53)$ & $3(10)$ \\
\hline & ALT $^{\mathrm{a}}$ increased & $73(45)$ & $32(48)$ & $70(53)$ & $3(10)$ \\
\hline & GGT $^{\mathrm{b}}$ increased & $60(37)$ & $22(33)$ & $53(40)$ & $7(23)$ \\
\hline & $\mathrm{ALP}^{\mathrm{c}}$ increased & $23(14)$ & $6(9)$ & $20(15)$ & $3(10)$ \\
\hline & $\mathrm{ChE}^{\mathrm{d}}$ decreased & $16(10)$ & $4(6)$ & $15(11)$ & $1(3)$ \\
\hline & Viremia ${ }^{\mathrm{e}}$ & $86(53)$ & $21(32)$ & $61(46)$ & $25(81)$ \\
\hline \multirow[t]{4}{*}{$\begin{array}{l}\text { Body Mass } \\
\text { Index }\end{array}$} & $<19$ Underweight & $4(3)$ & $3(6)$ & $4(3)$ & - \\
\hline & 19 to $<25$ Normal & $68(49)$ & $31(56)$ & $53(47)$ & $15(55)$ \\
\hline & 25 to $<30$ Overweight & $37(26)$ & $11(20)$ & $30(27)$ & $7(26)$ \\
\hline & $\geq 30$ Obesity & $31(22)$ & $10(18)$ & $26(23)$ & $5(19)$ \\
\hline $\begin{array}{l}\text { Regular } \\
\text { Physical } \\
\text { Activity }\end{array}$ & Yes & $52(32)$ & $21(32)$ & $40(46)$ & $12(40)$ \\
\hline Smoking & Yes & $26(16)$ & $16(24)$ & $24(18)$ & $2(7)$ \\
\hline \multirow[t]{2}{*}{ Mental Stress } & Fatigue & $121(74)$ & $47(71)$ & $100(76)$ & $21(68)$ \\
\hline & Depression & $60(35)$ & $21(32)$ & $50(39)$ & $10(34)$ \\
\hline
\end{tabular}

* \% based on valid values; * significant subgroup difference; HCC Hepatocellular Carcinoma; LTX Liver Transplantation; RWA Reduced Work Ability; norm values: ${ }^{a}$ AST Aspartate Transaminase \& ALT Alanine Transaminase $\$ \leq 10-35 \mathrm{IU} / \mathrm{L} ; o^{\top} \leq 10-50 \mathrm{IU} / \mathrm{L}^{\mathrm{b}}$ GGT Gamma-Glutamyl Transferase $+\leq 39 \mathrm{IU} / \mathrm{L} ; o^{\mathrm{\gamma}} \leq 66 \mathrm{IU} / \mathrm{L}^{\mathrm{c}}$ ALP Alkaline phosphatase $\$ 35-104 \mathrm{IU} / \mathrm{L} ; 0^{\top} 40-129 \mathrm{IU} / \mathrm{L}^{\mathrm{d}} \mathrm{ChE}$ Cholinesterase $\$ \& \&$ o from 40 years $>4620 \mathrm{IU} / \mathrm{L} ;{ }^{\mathrm{e}}$ above the detection limit DNA Desoxyribonucleic Acid $\leq 60 \mathrm{IU} / \mathrm{mL} ;$ RNA Ribonucleic Acid $\leq 15 \mathrm{IU} / \mathrm{mL}$.

The analysis of the subgroups by gender and type of hepatitis revealed significant differences in terms of consequences relating to occupational disease (Table 2). HBV patients had the disease for longer on average (three years) and had had a statistically significantly higher rate of cirrhosis than HCV patients $(43 \%$ vs. $25 \%, p=0.04)$. The median RWA in the entire cohort and among women was 
$30 \%$, while it was $50 \%$ among men $(p=0.004)$. Men had the disease for longer on average (three years) and had had statistically significantly more cirrhosis than women ( $44 \%$ vs. $24 \%, p=0.02)$.

Of the surveyed participants, just under half were of normal weight (BMI 19 to $<25$ ), $26 \%$ were overweight (BMI 25 to $<30$ ), $22 \%$ were obese (BMI $\geq 30$ ), and $3 \%$ were underweight (BMI $<19$ ). Stratification by gender and type of hepatitis demonstrated no significant differences, although only $\mathrm{HCV}$-infected women were underweight $(n=4)$. Overall, $32 \%$ of participants reported engaging in regular physical activity, and $16 \%$ of those surveyed were smokers (Table 2). There was a statistically significant difference in sports behavior; men were significantly more likely than women to engage in regular sports activities ( $48 \%$ vs. $27 \%, p=0.04)$.

Fatigue symptoms were documented in $74 \%$ of participants and depression in $37 \%$ of participants. Of those pre-treated with interferon, $80 \%$ had fatigue and $45 \%$ had depression; of those not pre-treated with interferon, $87 \%$ had fatigue symptoms and 33\% had depression $(p>0.05$ for fatigue and $p>$ 0.05 for depression, respectively, missing values $n=20$; Table 2). Neither gender, type of hepatitis, nor professional activity were associated significantly with fatigue and depression ( $p>0.05$ for each).

Drop-outs (Appendix A Table A1): The drop-out rate at T3 was 9\% $(n=14)$. At 59 (SD 8$)$ years, the average age was four years below the average value in the entire cohort. Eighty-six percent were women; 6 out of 14 insured persons were professionally active. Most of the insured persons had HCV $(86 \%)$, with the time of infection being between 20 and 40 years previously in $75 \%$ of cases. Half of the drop-outs had a RWA of $\geq 50 \%$. Six insured persons (43\%) stated that they regularly engaged in physical activity; three insured persons were smokers. In the clinical survey, fatigue was documented in $64 \%$ of the individuals and depression in $29 \%$ of them.

\subsection{Results of the Survey Based on Self-Assessment Questionnaires}

The overall results of the survey based on self-assessment questionnaires are presented in Table 3.

\subsubsection{WAI $(n=66)$}

WAI score: work ability measured with the WAI score was in the poor-to-moderate range upon admission (T1), improved to a statistically significant degree until end of treatment (T2), and remained at a moderate level six months later (mean values: T1 28.7, T2 30.5, T3 29.6; $p=0.02$ ). For the group of $\mathrm{HP}(n=15)$ who participated for a second time in the treatment program during the inclusion phase, a continuous, but not significant improvement was observed between T1 and T3 (T1 27.8, T2 28.8, T3 29.6; $p=0.4$; Figure 1).

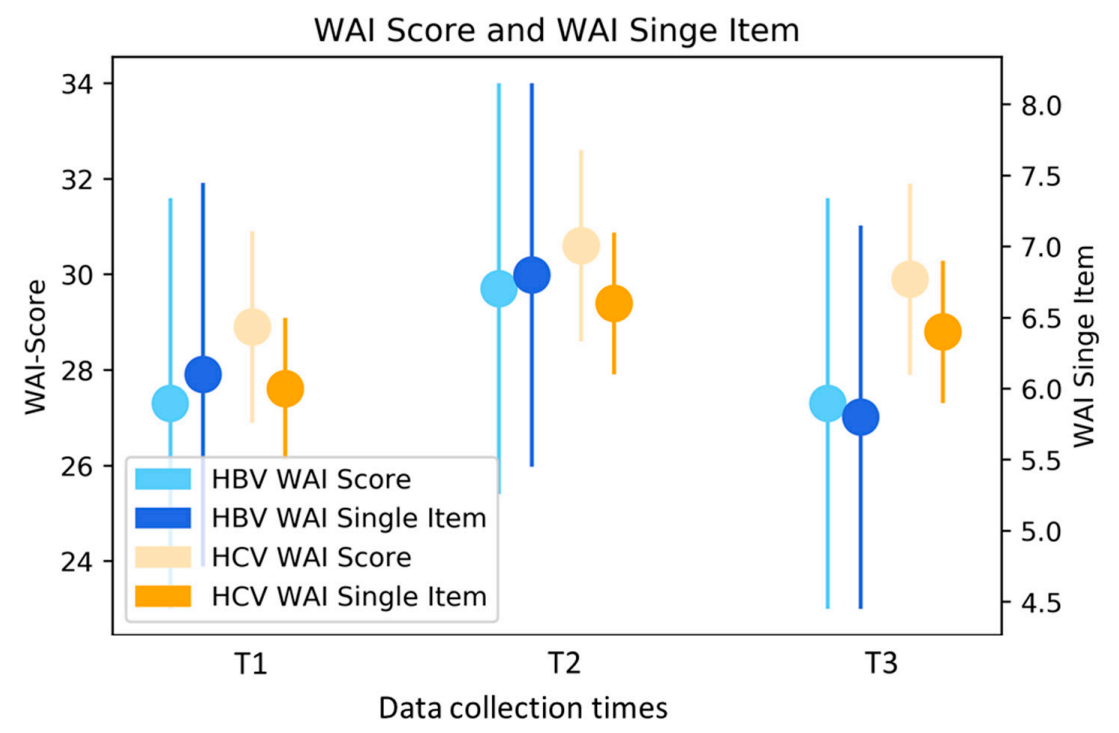

Figure 1. WAI Score and WAI Single-Item-mean values stratified by type of hepatitis and adjusted for age and gender. HBV Hepatitis B virus; HCV Hepatitis C virus; WAI Work Ability Index. 
WAI single item: measurement with the individual item also demonstrated work ability in a moderate range with a significant improvement directly after the treatment program (mean values: $\mathrm{T} 1$ 6.0, T2 6.6, T3 6.3; $p=0.006$; Figure 1).

\subsubsection{SF-36 $(n=160)$}

SF-36 Physical Health Summary Scale (PHSS): the results of the surveys on state of health (SF-36) showed no change over the observation period in terms of physical health for the entire cohort. At $<39 \mathrm{p}$, the adjusted mean values were below the average compared with the reference sample. When stratified according to the type of hepatitis, there was a statistically significant improvement in the HBV subgroup at $\mathrm{T} 2$ compared with $\mathrm{T} 1$, and at $\mathrm{T} 3$, these effects diminished and remained well below the initial value (Figure 2). Compared with the HCV subgroup, the participants with an HBV infection exhibited lower mean values. The multivariate analysis showed both age and gender-specific differences. Men had values $5.5 \mathrm{p}$ higher than those of women $(p=0.0009)$, and for each year of life, this scale demonstrated a decline of $0.4 \mathrm{p}$ for the participants overall $(p=0.0001)$. The gender-specific differences were greatest in the HBV subgroup, with men exhibiting values $7.0 \mathrm{p}$ higher than women $(p=0.02)$.

SF-36 Mental Health Summary Scale (MHSS): the results for mental health showed mean values below the average compared with the reference sample for the entire cohort with a significant improvement directly after the treatment program (mean values: T1 40.2, T2 44.0, T3 40.4; $p=0.01$, Figure 2). When stratified according to the type of hepatitis, there were also statistically significant short-term improvements in the HCV subgroup. In the multivariate analysis, there was a statistically significant age effect with an increase of 0.2 p per year of life $(p=0.01)$.

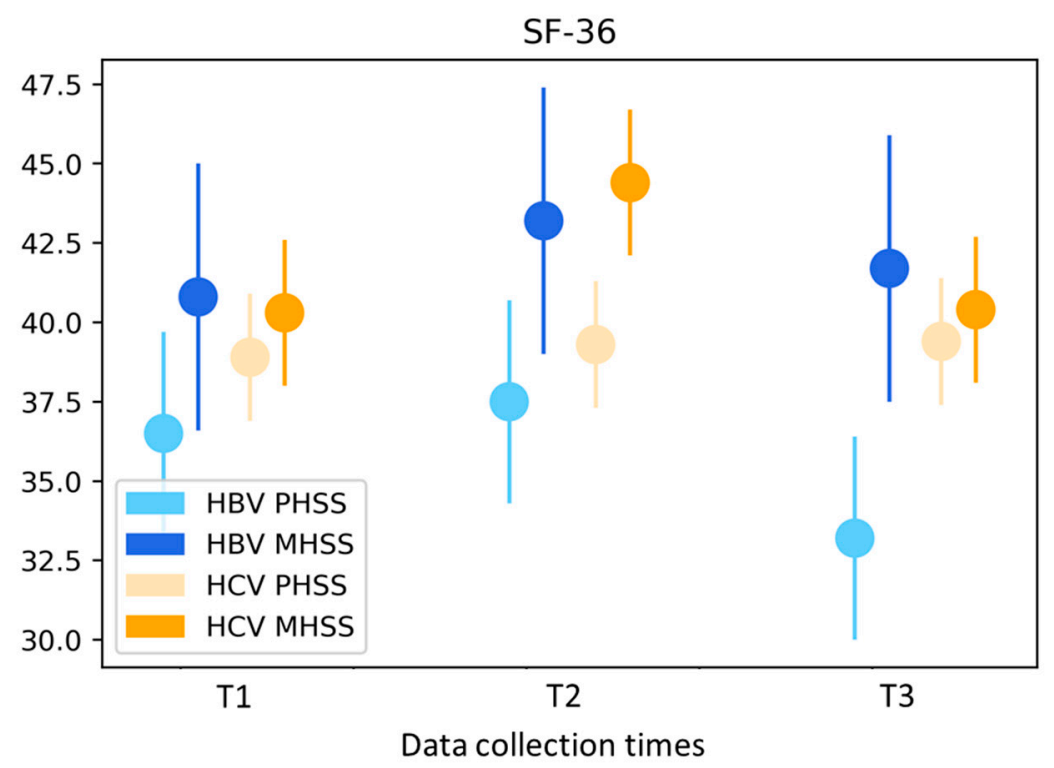

Figure 2. Short Form-36 Health Survey (SF-36) - mean values stratified by type of hepatitis and adjusted for age and gender. HBV hepatitis B virus; HCV hepatitis C virus; PHSS SF-36 Physical Health Summary Scale; MHSS SF-36 Mental Health Summary Scale.

\subsubsection{HADS-D $(n=159)$}

The results of the HADS-D indicate noteworthy anxiety and depression symptoms in the study cohort. The adjusted mean values for the two scales (anxiety and depression) remained of noteworthy relevance throughout the entire study period (mean values for entire cohort in relation to anxiety: T1 11.4, T2 12.0, T3 11.6; $p=0.006$; mean values for depression: T1 11.3, T2 11.2, T3 11.3; $p>0.05$; Figure 3). Both in the entire cohort and in the HCV subgroup, a statistically significant increase in anxiety symptoms was observed at $\mathrm{T} 2$ relative to $\mathrm{T} 1$. In the multivariate analysis, there were 
gender-specific differences observable in the entire cohort. Men had values $1.0 \mathrm{p}$ higher than those of women $(p=0.006)$. This difference was more pronounced in the HBV subgroup, with men exhibiting values $2.6 \mathrm{p}$ higher than women $(p=0.002)$.

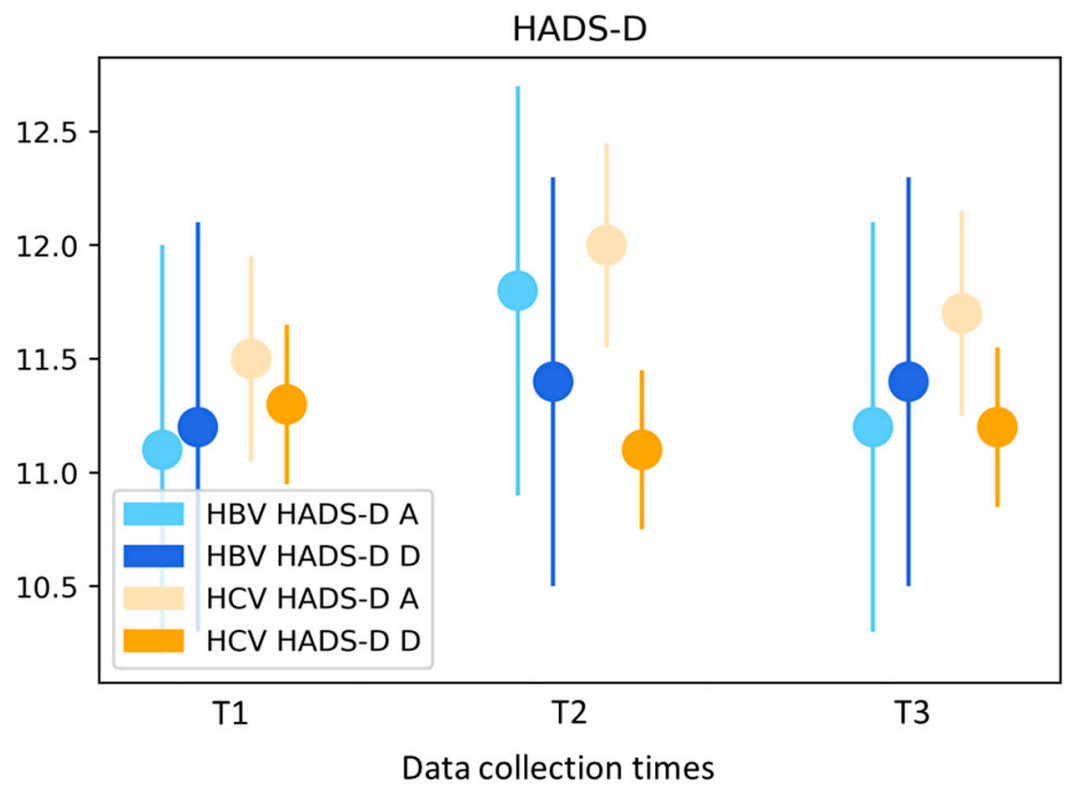

Figure 3. Hospital Anxiety and Depression Scale (HADS-D)—mean values stratified by type of hepatitis and adjusted for age and gender. HBV hepatitis B virus; HCV hepatitis C virus; HADS-D A Hospital Anxiety Scale; HADS-D D Hospital Depression Scale.

\subsection{Satisfaction Survey at $\mathrm{T} 2$}

The survey performed directly after the treatment program revealed a high level of satisfaction among participants with the medical care provided by both the physicians $(98 \%)$ and by the nursing and assistance staff $(95 \%)$. The insured persons also stated that they were satisfied overall with the inpatient physiotherapy measures (97\%), physical care $(98 \%)$, and psychological counselling $(96 \%)$. The most commonly specified rehabilitation objective was physical (and mental) stabilisation in conjunction with care provided by specialist physicians. A total of $91 \%$ of participants stated at T2 that they had achieved the majority of their objectives (Appendix A Table A2). Stratification according to gender and type of hepatitis revealed no significant differences.

Survey results in the drop-out cohort revealed $100 \%$ satisfaction with both the medical care and the inpatient measures of the treatment program (no table). 
Table 3. Survey results-mean values from the overall cohort and stratified by type of hepatitis.

\begin{tabular}{|c|c|c|c|c|c|c|c|c|c|c|c|c|}
\hline \multirow[t]{3}{*}{ Variable } & \multicolumn{4}{|c|}{ Total } & \multicolumn{4}{|c|}{$\mathrm{HCV}$} & \multicolumn{4}{|c|}{ HBV } \\
\hline & \multicolumn{4}{|c|}{ Mean ${ }^{1}(95 \%-C I)$} & \multicolumn{4}{|c|}{ Mean ${ }^{1}(95 \%-C I)$} & \multicolumn{4}{|c|}{ Mean $^{1}(95 \%-C I)$} \\
\hline & $N$ & T1 & T2 & T3 & $N$ & T1 & T2 & T3 & $N$ & T1 & $\mathrm{T} 2$ & T3 \\
\hline \multicolumn{13}{|l|}{ SF-36 } \\
\hline PHSS \#, & 160 & $\begin{array}{c}38.4 \\
(36.7-40.1)\end{array}$ & $\begin{array}{c}38.8 \\
(37.2-40.5)\end{array}$ & $\begin{array}{c}38.2 \\
(36.5-39.9)\end{array}$ & 129 & $\begin{array}{c}38.9 \\
(36.9-40.9)\end{array}$ & $\begin{array}{c}39.3 \\
(37.3-41.3)\end{array}$ & $\begin{array}{c}39.4 \\
(37.4-41.4)\end{array}$ & 29 & $\begin{array}{c}36.5 \\
(33.3-39.6)\end{array}$ & $\begin{array}{c}37.5^{*} \\
(34.3-40.7)\end{array}$ & $\begin{array}{c}33.2 \\
(30.1-36.4)\end{array}$ \\
\hline MHSS \# & 160 & $\begin{array}{c}40.2 \\
(38.2-42.2)\end{array}$ & $\begin{array}{c}44.0 * \\
(42.0-46.0)\end{array}$ & $\begin{array}{c}40.4 \\
(38.4-42.4)\end{array}$ & 129 & $\begin{array}{c}40.3 \\
(38.0-42.6)\end{array}$ & $\begin{array}{c}44.4^{*} \\
(42.1-46.7)\end{array}$ & $\begin{array}{c}40.4 \\
(38.0-42.7)\end{array}$ & 29 & $\begin{array}{c}40.8 \\
(36.6-45.0)\end{array}$ & $\begin{array}{c}43.2 \\
(38.9-47.4)\end{array}$ & $\begin{array}{c}41.7 \\
(37.5-45.8)\end{array}$ \\
\hline \multicolumn{13}{|l|}{ HADS-D } \\
\hline$A^{\S}$ & 159 & $\begin{array}{c}11.4 \\
(11.0-11.8)\end{array}$ & $\begin{array}{c}12.0 * \\
(11.6-12.4)\end{array}$ & $\begin{array}{c}11.6 \\
(11.2-12.1)\end{array}$ & 129 & $\begin{array}{c}11.5 \\
(11,0-11,9)\end{array}$ & $\begin{array}{c}12.0^{*} \\
(11.6-12.5)\end{array}$ & $\begin{array}{c}11.7 \\
(11.2-12.2)\end{array}$ & 30 & $\begin{array}{c}11.1 \\
(10.2-12.0)\end{array}$ & $\begin{array}{c}11.8 \\
(11.0-12.7)\end{array}$ & $\begin{array}{c}11.2 \\
(10.3-12.1)\end{array}$ \\
\hline $\mathrm{D}$ & 159 & $\begin{array}{c}11.3 \\
(11.0-11.6)\end{array}$ & $\begin{array}{c}11.2 \\
(10.9-11.5)\end{array}$ & $\begin{array}{c}11.3 \\
(10.9-11.6)\end{array}$ & 129 & $\begin{array}{c}11.3 \\
(10.9-11.6)\end{array}$ & $\begin{array}{c}11.1 \\
(10.7-11.5)\end{array}$ & $\begin{array}{c}11.2 \\
(10.8-11.6)\end{array}$ & 29 & $\begin{array}{c}11.2 \\
(10.3-12.1)\end{array}$ & $\begin{array}{c}11.4 \\
(10.5-12.3)\end{array}$ & $\begin{array}{c}11.4 \\
(10.5-12.2)\end{array}$ \\
\hline \multicolumn{13}{|l|}{$\begin{array}{l}\text { Working } \\
\text { WAI }\end{array}$} \\
\hline Score & 66 & $\begin{array}{c}28.7 \\
(26.9-30.5)\end{array}$ & $\begin{array}{c}30.5 * \\
(28.7-32.3)\end{array}$ & $\begin{array}{c}29.6 \\
(27.8-31.4)\end{array}$ & 56 & $\begin{array}{c}28.9 \\
(26.9-30.9)\end{array}$ & $\begin{array}{c}30.6 \\
(28.6-32.6)\end{array}$ & $\begin{array}{c}29.9 \\
(27.9-32.0)\end{array}$ & 10 & $\begin{array}{c}27.3 \\
(23.2-31.4)\end{array}$ & $\begin{array}{c}29.7 \\
(25.3-34.1)\end{array}$ & $\begin{array}{c}27.3 \\
(22.8-31.8)\end{array}$ \\
\hline $\begin{array}{l}\text { Single } \\
\text { Item }\end{array}$ & 66 & $\begin{array}{c}6.0 \\
(5.5-6.4)\end{array}$ & $\begin{array}{c}6.6 * \\
(6.2-7.1)\end{array}$ & $\begin{array}{c}6.3 \\
(5.8-6.7)\end{array}$ & 56 & $\begin{array}{c}6.0 \\
(5.5-6.5)\end{array}$ & $\begin{array}{c}6.6 * \\
(6.1-7.1)\end{array}$ & $\begin{array}{c}6.4 \\
(5.8-6.9)\end{array}$ & 10 & $\begin{array}{c}6.1 \\
(4.9-7.3)\end{array}$ & $\begin{array}{c}6.8 \\
(5.5-8.2)\end{array}$ & $\begin{array}{c}5.8 \\
(4.4-7.2)\end{array}$ \\
\hline
\end{tabular}

${ }^{1}$ Adjusted for age and gender; CI confidence interval; PHSS Physical Health Summary Scale (range 0-100); MHSS Mental Health Summary Scale (range 0-100); A anxiety (range 0-21); D depression (range 0-21); WAI score (range 7-49); WAI single item (range 0-10); HCV hepatitis C virus; HBV hepatitis B virus; * Significant time effect compared with T1, $p<0.05$; \# Significant age effect on the subscale, $p<0.05$; Significant gender effect on the subscale, $p<0.05$. 


\section{Discussion}

This is the first study to examine the impact of inpatient rehabilitation measures on work ability and the health-related quality of life among HP with chronic hepatitis. At the start of the rehabilitation, on average, work ability and quality of life were low and positive effects were observable for both. Six months later, these effects were somewhat diminished, but the scores remained above their initial values. Despite these short-term effects of the rehabilitation, participants were satisfied overall with the treatment program. The majority stated having achieved their rehabilitation objectives. There were no indications of distortion caused by non-participation in the study or by drop-outs at T3, as the demographic characteristics among participants and non-participants were comparable.

The participants in this pre-post design evaluation study were mainly retired health workers with long therapy experience, suffering from viral hepatitis (C). The chronic viral hepatitis was progressed as well in the entire cohort and in the professionally-active subgroup, with over $90 \%$ having liver fibrosis or cirrhosis. Gender-specific, statistically significant differences existed in terms of the RWA level and net household income. The majority of men (75\%) had an RWA above the overall median $(30 \%)$ and had a higher net household income than women. The results of surveys on work ability indicate a discrepancy between work requirements and individual performance capacity in the professionally-active subgroup of insured persons. Professionally-active HPs with a chronic disease are subject not only to the specific work-related challenges, but also numerous physical and mental problems [14]. Without targeted support measures, work ability declines with age by an average of 0.4 WAI points per year [15]. This age effect was observable in the study cohort. There were also work-specific (such as decision-making capacity and personal importance of work) and individual factors (such as regular physical activity) that had a favorable or adverse (chronic disease) impact on work ability [16,17]. Reduced functionality of the musculoskeletal system and heavy physical and mental stress are associated with a poor WAI $[17,18]$.

The analyses of quality of life (SF-36 PHSS) revealed below-average mean values for the entire cohort compared with the reference sample. Although the median RWA of $30 \%$ among women was significantly lower than for men (50\%), men exhibited significantly better physical health. They engaged significantly much more frequently in regular physical activity compared with women $(48 \% \mathrm{vs} .27 \%$, $p=0.04)$. The HADS-D studies, an instrument that measures mental stress among somatic patients, revealed noteworthy or even pathological anxiety and depression values in the study cohort. Men had significantly more noteworthy values in the anxiety scale compared with women. The results of the clinical study also demonstrated mental stress in the entire cohort. Two-thirds exhibited fatigue symptoms, while one-third of the cohort suffered from depression. In a recent prospective study from Germany, which recorded persistent neuropsychiatric impairments among 159 patients with chronic HCV infections, $85 \%$ of participants exhibited fatigue, $50 \%$ to $60 \%$ exhibited mild depression or anxiety, $45 \%$ exhibited memory impairment, and 30\% suffered from attention deficit disorders. Fatigue had the greatest adverse impact on the outcome of health-related quality of life (HRQoL). This negative correlation was statistically significant $(p<0.001)$ and persisted despite a state of aviremia being achieved [19]. In a case-control study with 189 patients with chronic HBV and HCV infections without cirrhosis, a multivariate regression analysis showed HCV infection and depression to be independent predictors for a statistically significantly reduced PHSS. The authors named anxiety, depression, fatigue, and marital status (single) as being independent predictors for a statistically significantly reduced MHSS [20]. Female gender and a reduced sense of coherence were demonstrated to be predictors for depression among patients with chronic HCV. Higher depression values were statistically significant in relation to marital status (single), female gender, and a recent $\mathrm{HCV}$ diagnosis. Compared with control groups without $\mathrm{HCV}$ infection, $\mathrm{HCV}$ infection was associated with statistically significantly higher depression values and a broader spectrum of psychological symptoms $(p=0.001)$ [21].

Interferon therapy for treating viral hepatitis is also associated with a reduced health-related quality of life [22]. HCV treatment was based on interferon- $\alpha$, a drug with cytotoxic properties, until direct-acting antiviral agents (DAA) were developed. HBV infections are still treated with 
interferon-based therapy, depending on medical history. PEG-IFN-based treatments potentially involve severe and sometimes persistent side effects. In the past, adverse events would frequently result in medically-induced abandonment of treatment. Pronounced side effects such as depression and long treatment times, sometimes with low success rates, had a negative impact on therapy compliance among patients, sometimes resulting in severe progression of the disease [23-26]. In the subgroup of the study of participants who had received interferon treatment, around one-third suffered from persistent side effects. Progressions with liver cell carcinoma and liver transplantation could be observed in the overall collective, as well as in the subgroup of the working population. Viremia was demonstrable among $53 \%$ of participants $(n=86)$ upon admission. Treatment was recommended for all participants with viremia in Wartenberg. Information on the administration of antiviral therapy following rehabilitation in Wartenberg was not available at the time of data analysis.

Other factors, such as obesity, can also have an influence on disease progression. Carrat et al. [27] found, in a prospective study in adult patients with chronic HCV infection enrolled from 32 expert hepatology centres in France, an independent relation between all-cause mortality and BMI <18.5. They also reported an independent relation between decompensated cirrhosis and BMI 25 to $<30$. In the present study, $26 \%$ of participants were overweight (BMI 25 to $<30$ ), $22 \%$ were obese (BMI $\geq 30$ ), and $3 \%$ were underweight $(\mathrm{BMI}<19)$.

Overall, $95 \%$ or more of the participants were satisfied with the medical care and inpatient measures of the treatment program. A total of $91 \%$ of participants stated that they had achieved the majority of their objectives. The most commonly named objective was the stabilisation of their health situation in connection with care provided by hepatologists.

\section{Limitations and Strengths}

The case numbers presented here exceed the target case count of 141 test subjects, but the number of professionally-active subjects in the cohort is much lower $(n=66)$. The WAI was only used for professionally-active participants. Participants of working age who have been unable to work for a prolonged period as a result of chronic infection have not been taken into account. This results in the WAI potentially overestimating the net work ability in the cohort. The lack of a control group also needs to be considered as a limitation of the relevance of the study results. Another limitation lies in the recording of the clinical parameters only at the time of admission. These were not recorded upon discharge or six months after. In particular, there was no record of whether DAA therapy had since been administered with HC viremia persistence. Successful DAA therapy may have positively influenced the information on work ability and quality of life at T3, which is why caution is required when interpreting the observed positive effects. On the other hand, the statistical power, the longitudinal approach, and method variance had a positive effect on the relevance of the study results. In addition to the self-assessment instruments, clinical parameters and mental stress were recorded in the medical consultation. The response rate of over $60 \%$ and the low drop-out rate had a positive impact on the representativeness of the sample population. The drop-out analysis demonstrated no systematic differences in terms of the baseline profile at the start of the treatment program or satisfaction with the medical care and inpatient measures.

\section{Conclusions}

The results of the surveys on work ability, quality of life, and anxiety and depression showed mean values that were in the medium to pathological range. The inpatient rehabilitation program proved to be effective in the short term in the field of mental health, as measured by SF-36. Regarding work ability, there was a statistically significant and also short-term improvement observable among the professionally-active subgroup. To ensure long lasting positive effects, services aimed at enhancing physical and mental health should be provided as early as possible and on a recurring basis. Aside from early diagnosis, an important tool for the preservation of health and work ability is adequate treatment of chronic viral hepatitis to prevent consequences from occupational diseases. The currently 
available and effective course of DAA treatments for $\mathrm{HCV}$ infections will potentially be able to prevent progressions such as those observable in the majority of cases in this study cohort.

Author Contributions: Conceptualization, C.W. and A.N.; methodology, C.W., A.T., and A.N.; formal analysis, A.T. and C.W.; investigation, A.T. and C.W.; data curation, C.W.; writing-original draft preparation, C.W.; writing—review and editing, C.W., A.T., and A.N.; supervision, A.N.; project administration, C.W.

Funding: This research received no external funding. However, the Institute for Health Services Research in Dermatology and Nursing of the University Medical Centre Hamburg-Eppendorf (UKE) receives an unrestricted fund from the BGW on an annual basis to maintain the working group at the UKE. The funds are provided by a non-profit organization that is part of the social security system in Germany. The funder had no role in study design, data collection and analysis, decision to publish, or preparation of the manuscript.

Acknowledgments: We would like to thank the Department of Occupational Medicine (BGW) for their support, in particular Dana Wendeler. Special thanks go to the Wartenberg Clinic and its medical staff, in particular Schneider. We would also like to thank Kolbeck for her administrative support.

Conflicts of Interest: The authors declare no conflict of interest.

\section{Appendix A}

Table A1. Drop-out details $(n=14)$.

\begin{tabular}{|c|c|c|}
\hline \multicolumn{2}{|c|}{ Variable * } & \multirow{2}{*}{$\begin{array}{c}\text { Total } \\
12(86)\end{array}$} \\
\hline Gender & Female & \\
\hline & Male & $2(14)$ \\
\hline Age & Mean (SD) & $59(8)$ \\
\hline Working & Yes & $6(43)$ \\
\hline \multirow{2}{*}{ Type of Hepatitis } & B & $2(14)$ \\
\hline & C & $12(86)$ \\
\hline \multirow[t]{2}{*}{ Place of birth } & Germany & $10(71)$ \\
\hline & Other & $4(29)$ \\
\hline \multirow[t]{3}{*}{ Household } & Single & $7(50)$ \\
\hline & With Partner and Child(s) & $6(43)$ \\
\hline & With Child(s) & $1(7)$ \\
\hline \multirow[t]{4}{*}{ Occupation } & Physician & $1(15)$ \\
\hline & Nurses & $5(38)$ \\
\hline & Nursing Home Nurse & $2(15)$ \\
\hline & Nurse's Assistant & $4(32)$ \\
\hline \multirow[t]{3}{*}{ Net household income in $€$} & $<2000$ & $7(58)$ \\
\hline & 2000 to $<4000$ & $3(25)$ \\
\hline & $\geq 4000$ & $2(17)$ \\
\hline \multirow[t]{3}{*}{ Chronic Hepatitis for } & $10-19$ years & $3(25)$ \\
\hline & $20-29$ years & $7(58)$ \\
\hline & $30-39$ years & $2(17)$ \\
\hline \multirow[t]{3}{*}{ Liver Status } & Fibrosis & $8(66)$ \\
\hline & Cirrhosis & $5(28)$ \\
\hline & Without Findings & $1(6)$ \\
\hline \multirow[t]{2}{*}{ RWA } & $<50$ & $7(50)$ \\
\hline & $\geq 50$ & $7(50)$ \\
\hline \multirow[t]{3}{*}{ Body Mass Index } & 19 to $<25$ Normal & $6(43)$ \\
\hline & 25 to $<30$ Overweight & $5(36)$ \\
\hline & $\geq 30$ Obesity & $3(21)$ \\
\hline Regular Physical Activity & Yes & $6(43)$ \\
\hline Smoking & Yes & $3(21)$ \\
\hline \multirow[t]{2}{*}{ Mental Stress } & Fatigue & $9(64)$ \\
\hline & Depression & $4(29)$ \\
\hline
\end{tabular}

*\% based on valid values; RWA reduced work ability. 
Table A2. Therapy satisfaction and individuals' goals for rehabilitation.

\begin{tabular}{ccc}
\hline Variable $^{\mathbf{1}}$ & \multicolumn{2}{c}{ Total } \\
\hline & $n$ & $\%$ \\
\hline Physician care & 159 & 98 \\
Nursing and assistance staff & 155 & 95 \\
Physiotherapy & 158 & 97 \\
Physical care & 159 & 98 \\
Psychological care & 78 & 96 \\
Catering & 156 & \\
Objectives pursued & & \\
(multiple nominations) & & 56 \\
Specialist medical care & 91 & 58 \\
Physical stabilisation & 94 & 50 \\
Mental stabilisation & 82 & 96 \\
Other ${ }^{2}$ & 14 & \\
\hline Main goals achieved & & 91 \\
\hline Yes & 148 & \\
\hline
\end{tabular}

$1 \%$ based on valid values; ${ }^{2}$. Contacts to other people, coming to rest; weight optimization.

\section{References}

1. World Health Organization. Global Hepatitis Report 2017; Licence: CC BY-NC-SA 3.0 IGO; World Health Organization: Geneva, Switzerland, 2017; p. 83. Available online: http://www.who.int/hepatitis/publications/ global-hepatitis-report2017/en/ (accessed on 6 August 2019).

2. World Health Organization. Guidelines for the Prevention, Care and Treatment of Persons with Chronic Hepatitis B Infection; World Health Organization: Geneva, Switzerland, 2015; Available online: https://www.who.int/hiv/ pub/hepatitis/hepatitis-b-guidelines/en/ (accessed on 6 August 2019).

3. Blachier, M.; Leleu, H.; Peck-Radosavljevic, M.; Valla, D.C.; Roudot-Thoraval, F. The burden of liver disease in Europe: A review of available epidemiological data. J. Hepatol. 2013, 58, 593-608. [CrossRef] [PubMed]

4. Gomaa, A.I.; Waked, I. Recent advances in multidisciplinary management of hepatocellular carcinoma. World J. Hepatol. 2015, 7, 673-687. [CrossRef] [PubMed]

5. Deuffic-Burban, S.; Delarocque-Astagneau, E.; Abiteboul, D.; Bouvet, E.; Yazdanpanah, Y. Blood-borne viruses in health care workers: Prevention and management. J. Clin. Virol. 2011, 52, 4-10. [CrossRef] [PubMed]

6. Quelhas, R.; Lopes, A. Psychiatric problems in patients infected with hepatitis C before and during antiviral treatment with interferon-alpha: A review. J. Psychiatr. Pract. 2009, 15, 262-281. [CrossRef] [PubMed]

7. Hilsabeck, R.C.; Hassanein, T.I.; Carlson, M.D.; Ziegler, E.A.; Perry, W. Cognitive functioning and psychiatric symptomatology in patients with chronic hepatitis C. J. Int. Neuropsychol. Soc. JINS 2003, 9, 847-854. [CrossRef] [PubMed]

8. Dulon, M.; Wendeler, D.; Nienhaus, A. Berufsbedingte Infektionskrankheiten bei Beschäftigten im Gesundheitsdienst 2017: Routinedaten der Berufsgenossenschaft für Gesundheitsdienst und Wohlfahrtspflege. Zentralblatt für Arbeitsmedizin Arbeitsschutz und Ergonomie 2019, 69, 16-22. [CrossRef]

9. Hasselhorn, H.M.; Freude, G. Der Work Ability Index. Ein Leitfaden (Schriftenreihe der Bundesanstalt für Arbeitsschutz und Arbeitsmedizin Sonderschrift, Bd. 87); Fachverlag NW in Carl Ed. Schünemann KG: Bremerhaven, Germany, 2007.

10. Gould, R.; Ilmarinen, J.; Järvisalo, J.; Koskinen, S. Dimensions of Work Ability—Results of the Health 2000 Survey; Finnish Institute of Occupational Health (FIOH): Helsinki, Finland, 2008.

11. Morfeld, M.; Kirchberger, I.; Bullinger, M. SF-36 Fragebogen zum Gesundheitszustand: Deutsche Version des Short Form-36 Health Survey; Hofgrefe: Göttingen, Germany, 2011; Volume 2, ergänzte und überarbeitete Auflage.

12. Hermann-Lingen, C.; Buss, U.; Snaith, R.P. Hospital Anxiety and Depression Scale-Deutsche Version (HADS-D); Verlag Hans Huber: Bern, Switzerland, 2011; Volume 3, aktualisierte und neu normierte Auflage. 
13. Walters, S.J. Sample size and power estimation for studies with health related quality of life outcomes: A comparison of four methods using the SF-36. Health Qual. Life Outcomes 2004, 2, 26. [CrossRef] [PubMed]

14. Klein, M.; Halsbeck, J. Mit chronischer Krankheit arbeiten (k)ein Problem? ASU Arb. Soz. Umweltmed. 2015, 50, 788-793.

15. Prümper, J.; Richenhagen, G. Von der Arbeitsunfähigkeit zum Haus der Arbeitsfähigkeit. In Der Work Ability Index und Seine Anwendung; Seyfried, B., Ed.; Bertelsmann: Bielefeld, Germany, 2011.

16. Converso, D.; Sottimano, I.; Guidetti, G.; Loera, B.; Cortini, M.; Viotti, S. Aging and Work Ability: The Moderating Role of Job and Personal Resources. Front. Psychol. 2017, 8, 2262. [CrossRef] [PubMed]

17. Koolhaas, W.; van der Klink, J.J.; de Boer, M.R.; Groothoff, J.W.; Brouwer, S. Chronic health conditions and work ability in the ageing workforce: The impact of work conditions, psychosocial factors and perceived health. Int. Arch. Occup. Environ. Health 2014, 87, 433-443. [CrossRef] [PubMed]

18. Van den Berg, T.I.; Elders, L.A.; de Zwart, B.C.; Burdorf, A. The effects of work-related and individual factors on the Work Ability Index: A systematic review. Occup. Environ. Med. 2009, 66, 211-220. [CrossRef] [PubMed]

19. Dirks, M.; Pflugrad, H.; Haag, K.; Tillmann, H.L.; Wedemeyer, H.; Arvanitis, D.; Hecker, H.; Tountopoulou, A.; Goldbecker, A.; Worthmann, H.; et al. Persistent neuropsychiatric impairment in HCV patients despite clearance of the virus? J. Viral Hepat. 2017, 24, 541-550. [CrossRef] [PubMed]

20. Ashrafi, M.; Modabbernia, A.; Dalir, M.; Taslimi, S.; Karami, M.; Ostovaneh, M.R.; Malekzadeh, R.; Poustchi, H. Predictors of mental and physical health in non-cirrhotic patients with viral hepatitis: A case control study. J. Psychosom. Res. 2012, 73, 218-224. [CrossRef] [PubMed]

21. Erim, Y.; Tagay, S.; Beckmann, M.; Bein, S.; Cicinnati, V.; Beckebaum, S.; Senf, W.; Schlaak, J.F. Depression and protective factors of mental health in people with hepatitis C: A questionnaire survey. Int. J. Nurs. Stud. 2010, 47, 342-349. [CrossRef] [PubMed]

22. Amodio, P.; Salari, L.; Montagnese, S.; Schiff, S.; Neri, D.; Bianco, T.; Minazzato, L. Hepatitis C virus infection and health-related quality of life. World J. Gastroenterol. WJG 2012, 18, 2295-2299. [CrossRef] [PubMed]

23. Heintges, T.; Erhardt, A.; Sagir, A.; Häussinger, D. Kombinationstherapie der chronischen Hepatitis C: Pegyliertes (PEG)-Interferon und Ribavirin. Dtsch. Arztebl.-Arztl. Mitt.-Ausg. A 2002, 99, 1239-1241.

24. Kohli, A.; Shaffer, A.; Sherman, A.; Kottilil, S. Treatment of hepatitis C: A systematic review. JAMA 2014, 312, 631-640. [CrossRef] [PubMed]

25. Kraus, M.R.; Wilms, K. Interferon- $\alpha$ Wirkung, Indikationen, Therapieüberwachung und Nebenwirkungen. Der Internist 2000, 41, 1399-1406. [CrossRef] [PubMed]

26. Vabo, I.L.; Ferreira, L.E.; Pace, F.H. Depressive Episode Incidence in Patients with Chronic Hepatitis C Treated with Pegylated Interferon and Ribavirin. Arq. Gastroenterol. 2016, 53, 20-24. [CrossRef] [PubMed]

27. Carrat, F.; Fontaine, H.; Dorival, C.; Simony, M.; Diallo, A.; Hezode, C.; De Ledinghen, V.; Larrey, D.; Haour, G.; Bronowicki, J.P.; et al. Clinical outcomes in patients with chronic hepatitis C after direct-acting antiviral treatment: A prospective cohort study. Lancet 2019, 393, 1453-1464. [CrossRef]

(C) 2019 by the authors. Licensee MDPI, Basel, Switzerland. This article is an open access article distributed under the terms and conditions of the Creative Commons Attribution (CC BY) license (http://creativecommons.org/licenses/by/4.0/). 